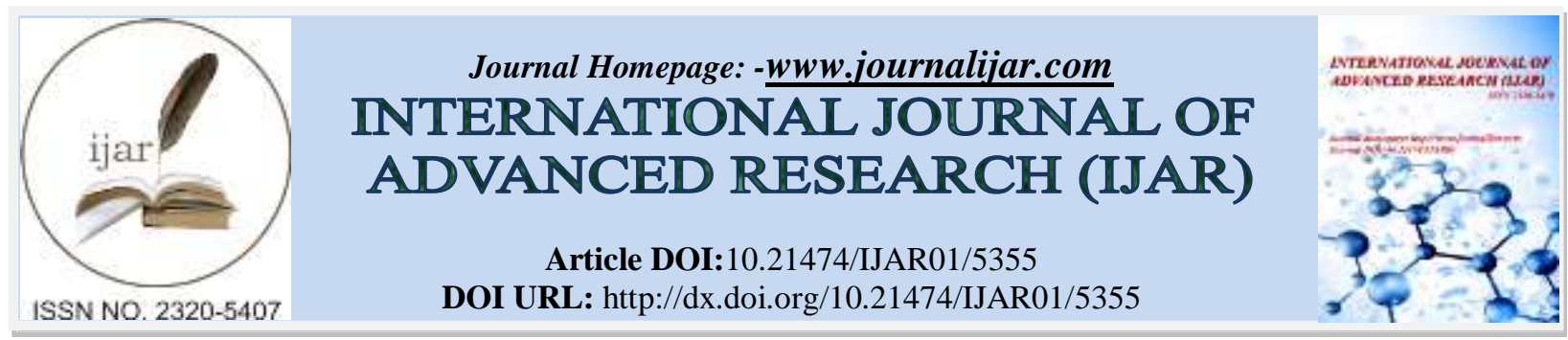

RESEARCH ARTICLE

\title{
QUALITY CHARACTERISTICS OF RESTRUCTURED CHICKEN CUBES INCORPORATING SPENT CHICKEN MEAT.
}

\section{Chetan S Khanapur ${ }^{1}$, Renuka Nayar ${ }^{2}$, Neethu Divakar ${ }^{1}$, Kavitha Rajagopal ${ }^{2}$, Sunanda $C^{3}$ and Magna Thomas ${ }^{4}$.}

1. MVSc Scholar, Department of Livestock Products Technology, College of Veterinary and Animal sciences, Pookode, Kerala Veterinary and Animal Sciences University, Pookode, Wayanad- 673 576, Kerala, India.

2. Assistant Professor, Department of Livestock Products Technology, College of Veterinary and Animal Sciences, Poolode, Wayanad- 673 576, Kerala, India.

3. Assistant Professor, Department of Biostatistics, College of Veterinary and Animal Sciences, Pookode, Wayanad-673 576, Kerala, India.

4. Assistant Professor, Department of Dairy Science, College of Veterinary and Animal Sciences, Pookode, Wayanad- 673 576, Kerala, India.

\section{Manuscript Info}

Manuscript History

Received: 07 July 2017

Final Accepted: 09 August 2017

Published: September 2017

Key words:-

Restructured meat, Spent chicken meat,

Ready-to-cook and Meat cubes.

\begin{abstract}
Tough meat from spent chicken can be economically utilized for preparing various convenience meat products which are nutritious and tasty. Ready-to-cook restructured chicken meat cubes were developed by incorporating spent chicken meat (SCM) into broiler chicken meat (BCM) at different ratios (T1, T2 and T3) and compared with broiler breast muscle cubes (C). Physico-chemical properties such as $\mathrm{pH}$, TBARS numbers and tyrosine values showed significant $(\mathrm{p}<0.01)$ difference between $C$ and treatments. Significantly $(p<0.01)$ higher $L$ and $\mathrm{b}$ values and lower a values were observed in $\mathrm{C}$ than treatments. Except for hardness, all texture parameters were significantly $(\mathrm{p}<0.01)$ lower for C. T2 and T3 showed significantly $(\mathrm{p}<0.01)$ higher aerobic plate count and $\mathrm{T} 2$ had higher yeast and mould count compared to others. C had significantly $(\mathrm{p}<0.01)$ lower protein, fat and ash contents than treatments. Overall acceptability scores were highest for $\mathrm{T} 1$ and then for $\mathrm{C}$ and $\mathrm{T} 2$. Spent hen meat can be incorporated up to 50 per cent level to prepare convenient, ready-to-cook restructured meat cubes.
\end{abstract}

Copy Right, IJAR, 2017,. All rights reserved.

\section{Introduction:-}

Present day consumers are concerned about their health and are careful in selecting their diet. A good diet is necessary to lead a healthy life and it can reduce the risk of diseases which would help in maintaining better health status and moreover a secure life. In recent days, there is a trend among consumers to include in their diet, meat products with less salt and fat content to minimize the adverse health effects.

Restructuring involves disassembling the carcass and reassembling it into same or different form which, gives a texture similar to the steaks, chops and roasts. The main objective of producing restructured meat products is to utilize the low value carcass trimmings or cuts from spent or aged animals to develop more palatable products which

Corresponding Author:-Chetan S Khanapur.

Address:-MVSc Scholar, Department of Livestock Products Technology, College of Veterinary and 521 
are marketed at higher cost. Poultry meat is most suitable for processing into various products due to the reasonable price, wide acceptance and mild flavour. Spent hen meat obtained as a byproduct from egg industry has higher fat and cholesterol content and also has poor sensory characteristics due to its tougher and less juicy nature and hence marketed at lower prices (Kumar et al., 2015). The binding of meat pieces during restructuring can be achieved by adding non-meat proteins like vegetable proteins, milk proteins, egg albumen, microbial transglutaminase etc. which improve the physico-chemical and functional properties and sensory attributes of the product. The extraction of myofibrillar proteins is usually enhanced by adding salt to the meat pieces and by subjecting to techniques like massaging, vacuum tumbling etc. which facilitates proper mixing of all added ingredients along with meat and also improves the raw binding ability of small meat pieces. Ready to eat or ready-to-cook restructured meat products have advantages of convenience in preparation and at the same time with added benefits of nutrients/ingredients which are incorporated during the formulation process. In this study, restructured chicken meat cubes were developed with incorporation of spent hen meat at different levels and compared with broiler breast meat cubes.

\section{Materials And Methods:-}

Broiler and spent chickens were procured from the local markets in Vythiri, Wayanad district and were brought to the Department of Livestock Products Technology, College of Veterinary and Animal Sciences, Pookode. The birds were provided adlibitum water and proper rest. They were slaughtered, dressed under hygienic conditions and the carcasses were washed and chilled overnight $\left(4 \pm 1^{0} \mathrm{C}\right)$. On the next day chilled carcasses were deboned and restructured chicken cubes were prepared and stored for further studies.

\section{Preparation of restructured chicken meat cubes:-}

The spent and broiler chicken carcasses were deboned separately. Deboned meat from spent chicken (SCM) and from broiler chicken (BCM) was used for the study. Three treatments of restructured meat were prepared incorporating SCM and BCM in proportions as shown in the Table 1.

In all the treatments seventy percent of the total meat was manually chunked into pieces of size $1.5 \mathrm{~cm}^{3}$ and thirty percent of the meat was coarse minced in a mincer. Both chunked and minced meat was mixed with salt as well as whipped egg albumen (1\% each) and subjected to vacuum tumbling (five minutes tumbling done twice with an interval of five minutes in between). Later the mixture was stuffed into suitable moulds of size $2 \times 2 \times 1.5 \mathrm{~cm}^{3}$ and kept for freezing at $-18 \pm 1^{0} \mathrm{C}$. On the next day, the formed cubes were removed from moulds and subjected to analyses.

\section{Physico-chemical characteristics:-}

$\mathrm{pH}$ of the samples was measured by using a digital $\mathrm{pH}$ meter as per AOAC (2012). Thiobarbituric acid reactive substances (TBARS) numbers were determined as per Witte et al. (1970) with modifications and the absorbance values measured at $530 \mathrm{~nm}$ were expressed as TBARS number of sample. Tyrosine values of the control and treatment samples were estimated as per the method described by Pearson (1968). The absorbance was measured at $660 \mathrm{~nm}$ in a spectrophotometer. By referring to the standard graph of tyrosine, tyrosine values of samples were calculated and expressed as mg of tyrosine $/ 100 \mathrm{~g}$ of sample.

Texture profile analysis was conducted as per Bourne (1978) using a Universal Testing Machine (TRAPEZIUM EZSX, Shimadzu, Japan). A crosshead speed of 10mm/min was used, applying $500 \mathrm{~N}$ load cell and texture parameters like hardness, springiness, cohesiveness and adhesiveness were estimated. Colour of the samples was determined objectively as per Page et al. (2001) using Hunter Lab Mini Scan XE Plus Spectrophotometer (Hunter Lab, Virginia, USA) with diffuse illumination. The colour coordinates L (lightness), a (redness) and b (yellowness) of the samples were measured thrice and mean values were taken.

The samples were also analysed for proximate principles like moisture, fat, protein and ash as per AOAC (2012) and carbohydrate and energy values were calculated.

\section{Microbiological parameters:-}

Aerobic plate count (APC) was evaluated as per the procedure of Morton (2001). Psychrotrophic count was expressed as per the procedure of Cousin et al. (2001). Yeast and mould count was expressed as per the procedure of Beuchat and Cousin (2001). The number of colonies was multiplied by the dilution factor and expressed as $\log _{10} \mathrm{cfu} / \mathrm{g}$. 


\section{Sensory attributes:-}

Sensory evaluation of control and treatment cubes was conducted by a semi-trained panel consisting of seven panellists from the Department of Livestock Products Technology, College of Veterinary and Animal Sciences, Pookode using a nine-point Hedonic scale as per (Badr et al., 2004). Cost involved in the product preparation was also estimated and statistical analysis was done for all the parameters as per the procedures of Snedecor and Cochran, (1994) using SPSS version 21.

\section{Result And Discussion:-}

Physico-chemical characteristics:-

$\mathrm{pH}$ values, TBARS numbers and tyrosine values of control and treatment cubes are presented in Table 2.

Significantly $(\mathrm{p}<0.01)$ lower $\mathrm{pH}$ values were recorded for $\mathrm{C}$ when compared to treatments. This might be because of the fact that $\mathrm{C}$ consisted of breast muscle which was white meat with more glycolytic metabolism and the higher $\mathrm{pH}$ in treatments might also be due to incorporation of egg albumen with alkaline $\mathrm{pH}$ during restructuring. Swatland (2008) observed lower $\mathrm{pH}$ values in pale breast muscle $(5.91 \pm 0.12)$ in comparison to dark breast muscle (6.36 \pm 0.25 ) in commercial broiler chicken. Gupta et al. (2017) stated that increase in $\mathrm{pH}$ of functional restructured spent hen meat blocks could be due to replacement of meat with different binders and extenders having slightly higher $\mathrm{pH}$ than meat.

TBARS number was significantly ( $\mathrm{p}<0.01)$ higher for $\mathrm{T} 3$ and lower for $\mathrm{C}$ and $\mathrm{T} 1$. The higher TBARS number for T3 might be due to the incorporation of spent chicken meat, which is rich in fat that might have undergone oxidation due to the various processes involved in the preparation of cubes. Biswas et al. (2006) also reported higher TBA values in duck patties due to higher fat content in comparison to spent hen and broiler meat patties and opined that higher fat percent was responsible for increased fat oxidation in patties. The present findings were in agreement with the results of Singh et al. (2011) who noted higher TBA values for chicken snack developed from mixture of spent chicken meat, rice flour, sodium caseinate and spice mix when compared to control. Chueachuaychoo et al. (2011) observed that spent hen meat had high fat percent and polyunsaturated fatty acid content due to which it was more prone to lipid oxidation.

Tyrosine values for T2 and T3 were significantly $(\mathrm{p}<0.05)$ higher when compared to control and T1. Sudheer et al. (2011) recorded higher tyrosine values for chicken blocks incorporated with gizzard when compared to control chicken blocks without gizzard.

The values obtained on instrumental texture and colour of control and treatment cubes are presented in Table 3. On instrumental texture profile analysis, $\mathrm{C}$ showed significantly $(\mathrm{p}<0.01)$ lower cohesiveness, springiness and adhesiveness values when compared to T1, T2 and T3. No significant difference was observed in the case of hardness among control and treatment cubes. Similar hardness values for control and treatment cubes on instrumental analysis might be due to the comminution of spent hen meat that might have reduced the effect of toughness. Similar findings were reported by Reddy et al. (2015) in restructured mutton products prepared with smaller particle size which had lower hardness values and it could be due to more retention of moisture in samples with smaller particle size. However, on sensory analysis, significantly higher toughness was noticed in T2 and T3 than $\mathrm{C}$ and $\mathrm{T} 1$.

Talukder et al. (2014) noticed significantly $(\mathrm{p}<0.05)$ higher hardness and adhesiveness values for restructured chicken meat blocks treated with hydrated lotus (Nelumbonucifera) root powder than control blocks and stated that it could be due to binding and gelling property of the vegetable extenders.

Hunter ' $\mathrm{L}$ ' value was significantly ( $\mathrm{p}<0.05$ ) higher for $\mathrm{C}$ than $\mathrm{T} 1$, $\mathrm{T} 2$ and $\mathrm{T} 3$ and might be due to that breast meat is white muscle and is lighter in colour. Ali et al. (2007) recorded lower lightness $\left(\mathrm{L}^{*}\right)$ values and higher $\left(\mathrm{a}^{*}\right)$ values in duck breast meat when compared to chicken breast which was due to more red muscle fibers in duck breast. Apart from that, lower $\mathrm{pH}$ of control cubes from breast portion might have resulted in lighter colour scores as reported by Fletcher (2002).

$\mathrm{C}$ had significantly $(\mathrm{p}<0.01)$ lower ' $a$ ' value and significantly $(\mathrm{p}<0.01)$ higher ' $\mathrm{b}$ ' value when compared to treatment cubes and might be due to the comparatively lower proportion of red muscle fibres in breast muscle. Nowsad et al. (2000) noticed that unwashed spent hen mince had shown decreased lighter $\left(\mathrm{L}^{*}\right)$ and increased redness $\left(\mathrm{a}^{*}\right)$ values in comparison to unwashed broiler mince. 
Results of proximate analysis are presented in Table 4. On proximate analysis, similar moisture levels were observed in all the samples, however fat and ash contents were significantly $(\mathrm{p}<0.05)$ lower for $\mathrm{C}$ than $\mathrm{T} 1$, T2 and T3. Fat percentage was the highest for T3. Higher fat and ash contents of treatments could be due to the incorporation of spent hen meat which is higher in these proximate principles. The protein content of T3 was significantly higher in comparison to C, T1 and T2. Reddy et al. (2016) reported different range of values for protein (21.25 to 23.46), fat (1.62 to 2.78), ash (1.22 to 1.29) and moisture content (71.05 to 73.15) in spent meat and the values were closer to the values obtained in the present study. Lakshani et al. (2016) recorded significantly $(\mathrm{p}<0.05)$ higher protein content in spent hen breast muscle than commercial broiler meat.

\section{Microbiological parameters:-}

Aerobic plate count and yeast and mould count obtained for control and treatment cubes are given in Table 5. Aerobic plate count and yeast and mould count were significantly $(p<0.01)$ lower for control when compared to treatment cubes. This might be due to the greater handling of meat and different steps involved in the processing of restructured chicken meat cubes. Luckose et al. (2015) opined that restructuring involved repeated handling of meat during product preparation which was highly prone for contamination and this could be avoided by proper storage.

\section{Sensory attributes:-}

In the raw cubes, appearance score was significantly lower for T2 and T3 when compared to $\mathrm{C}$ and might be due to the darker colour of the cubes due to more percentage of spent hen meat. Raw meat bind score was similar to all restructured meat cubes and all had high scores. In the case of cooked samples, significantly $(\mathrm{p}<0.01)$ lower value for appearance was noticed in T2 and T3 and might be due to the dark colour of cubes due to more incorporation of spent hen meat. Although flavour scores were similar for all, juiciness score was significantly $(\mathrm{p}<0.01)$ lower for T3. Tenderness score was significantly $(\mathrm{p}<0.01)$ lower for $\mathrm{T} 2$ and $\mathrm{T} 3$ when compared to $\mathrm{C}$ even though on instrumental analysis it was not significant. Lower tenderness scores in T2 and T3 might be due to the higher percentage of incorporation of spent hen meat. Guan et al. (2013) reported higher muscle fibre diameter in spent layer birds which was directly related to meat toughness and also opined that spent hen meat had lower sensory scores than other birds due to its more toughness. Score for overall acceptability was the highest for T1 and lowest for T3, with C and T2 having scores in between. Kalaikanan et al. (2007) reported that egg albumen had good emulsifying and binding properties in meat products and retained fat and moisture of products which attributed to increased juiciness of the end products.

\section{Cost of production:-}

The cost of production was found to be lowest for treatment samples when compared to control (boneless breast muscle cubes). The cost of C, T1, T2 and T3 were Rs. 270, Rs.238, Rs.243 and Rs.249 respectively, for one kg sample.

\section{Conclusion:-}

Restructured chicken meat cubes developed by incorporating spent chicken meat (SCM) and broiler chicken meat (BCM) showed acceptable physico-chemical, microbiological and sensory quality characteristics. Hence we can conclude that $\mathrm{T} 1$ had superior scores in all sensory attributes and lower cost of production than others and also showed lesser proteolysis and lipid oxidation in comparison to T 2 and T 3 samples. T 3 had the lowest sensory scores and was least accepted due to increased toughness. Spent chicken meat (SCM) can be incorporated upto 50 per cent level for economic production of restructured chicken cubes with good sensory attributes and can be conveniently used as a ready-to-cook meat product suitable for curries, fries, biriyanis etc.

\section{Acknowledgement:-}

Financial assistance received from Kerala Veterinary and Animal Sciences University for carrying out the research work is kindly acknowledged.

Table.1:-Preparation of treatment and control cubes.

\begin{tabular}{|l|l|l|}
\hline Treatments & Percentage of SCM & Percentage of BCM \\
\hline Treatment 1 (T1) & 25 & 75 \\
\hline Treatment 2 (T2) & 50 & 50 \\
\hline Treatment 3 (T3) & 75 & 25 \\
\hline
\end{tabular}


\begin{tabular}{|l|l|}
\hline Control & Broiler breast muscle cubes \\
\hline
\end{tabular}

Table 2:-Physico-chemical characteristics of control and treatment cubes.

\begin{tabular}{|l|l|l|l|}
\hline Sample & $\mathbf{p H}$ & TBARS number & $\begin{array}{l}\text { Tyrosine value(mg of tyrosine } \\
/ \mathbf{1 0 0 g} \text { sample) }\end{array}$ \\
\hline C & $5.76 \pm 0.012^{\mathrm{b}}$ & $0.015 \pm 0.002^{\mathrm{c}}$ & $0.075 \pm 0.011^{\mathrm{bc}}$ \\
\hline T1 & $5.85 \pm 0.012^{\mathrm{a}}$ & $0.017 \pm 0.002^{\mathrm{c}}$ & $0.058 \pm 0.008^{\mathrm{c}}$ \\
\hline T2 & $5.82 \pm 0.022^{\mathrm{a}}$ & $0.030 \pm 0^{\mathrm{b}}$ & $0.125 \pm 0.011^{\mathrm{a}}$ \\
\hline T3 & $5.75 \pm 0.007^{\mathrm{b}}$ & $0.038 \pm 0.002^{\mathrm{a}}$ & $0.100 \pm 0.013^{\mathrm{ab}}$ \\
\hline F-value & $7.858^{* * *}$ & $40.606^{* *}$ & $7.000^{*}$ \\
\hline P-value & 0.001 & $<0.001$ & 0.002 \\
\hline
\end{tabular}

Note:**-significant at $1 \%$ level, *- significant at $5 \%$ level, ns-non significant; Means having different alphabets as superscripts are significantly different within a column.

Table 3:-Texture profile parameters and Hunter $\mathrm{L}, \mathrm{a}, \mathrm{b}$ values of control and treatment cubes.

\begin{tabular}{|c|c|c|c|c|c|c|c|}
\hline Sample & Hardness & Springiness & Cohesiveness & Adhesiveness & L value & a value & b value \\
\hline $\mathrm{C}$ & $50.80 \pm 3.288$ & $0.392 \pm 0.003^{c}$ & $0.382 \pm 0.004^{c}$ & $0.093 \pm 0.004^{\mathrm{c}}$ & $\begin{array}{l}41.62 \\
0.082^{\mathrm{a}}\end{array}$ & $\begin{array}{l}6.58 \pm \\
0.137^{c}\end{array}$ & $\begin{array}{l}14.47 \pm \\
0.115^{\mathrm{a}}\end{array}$ \\
\hline T1 & $54.36 \pm 0.964$ & $0.593 \pm 0.018^{b}$ & $0.410 \pm 0.009^{b}$ & $0.124 \pm 0.009^{b}$ & $\begin{array}{l}37.20 \pm \\
0.243^{\mathrm{b}}\end{array}$ & $\begin{array}{l}8.75 \pm \\
0.165^{\mathrm{a}}\end{array}$ & $\begin{array}{l}12.25 \pm \\
0.139^{\mathrm{b}}\end{array}$ \\
\hline $\mathrm{T} 2$ & $48.19 \pm 1.449$ & $0.660 \pm 0.008^{\mathrm{a}}$ & $0.386 \pm 0.006^{\mathrm{c}}$ & $0.154 \pm 0.011^{\mathrm{a}}$ & $\begin{array}{l}36.49 \pm \\
0.236^{\mathrm{b}}\end{array}$ & $\begin{array}{l}9.18 \pm \\
0.157^{\mathrm{a}}\end{array}$ & $\begin{array}{l}10.69 \pm \\
0.045^{c}\end{array}$ \\
\hline T3 & $54.02 \pm 1.721$ & $0.634 \pm 0.005^{\mathrm{a}}$ & $0.432 \pm 0.007^{\mathrm{a}}$ & $0.147 \pm 0.006^{\mathrm{ab}}$ & $\begin{array}{l}36.42 \pm \\
0.622^{\mathrm{b}}\end{array}$ & $\begin{array}{l}7.64 \pm \\
0.196^{b}\end{array}$ & $\begin{array}{l}10.35 \pm \\
0.100^{d}\end{array}$ \\
\hline F-value & $2.020^{\mathrm{ns}}$ & $137.092^{* * *}$ & $11.303^{* *}$ & $12.037^{* *}$ & $48.471^{* *}$ & $49.912^{* *}$ & $316.528^{* * *}$ \\
\hline P-value & 0.144 & $<0.001$ & $<0.001$ & $(<0.001)$ & $<0.001$ & $<0.001$ & $<0.001$ \\
\hline
\end{tabular}

Note:**-significant at $1 \%$ level, $*$ - significant at $5 \%$ level, ns-non significant; Means having different alphabets as superscripts are significantly different within a column.

Table 4:-Proximate principles of control and treatment cubes.

\begin{tabular}{|l|l|l|l|l|l|}
\hline Proximates & C & T 1 & T & T 3 & $\begin{array}{l}\text { F-value } \\
\text { (p-value) }\end{array}$ \\
\hline Moisture & $74.40 \pm 0.402$ & $74.98 \pm 0.135$ & $74.43 \pm 0.138$ & $75.22 \pm 0.191$ & $\begin{array}{l}2.779^{\text {ns }} \\
(0.068)\end{array}$ \\
\hline Fat & $0.74 \pm 0.072^{\mathrm{c}}$ & $2.07 \pm 0.185^{\mathrm{b}}$ & $2.25 \pm 0.178^{\mathrm{b}}$ & $2.99 \pm 0.330^{\mathrm{a}}$ & $\begin{array}{l}19.558^{* *} \\
(<0.001)\end{array}$ \\
\hline Protein & $20.25 \pm 0.196^{\mathrm{b}}$ & $19.64 \pm 0.090^{\mathrm{b}}$ & $19.86 \pm 0.323^{\mathrm{b}}$ & $21.70 \pm 0.213^{\mathrm{a}}$ & $\begin{array}{l}17.602^{* *} \\
(<0.001)\end{array}$ \\
\hline Ash & $2.08 \pm 0.252^{\mathrm{b}}$ & $3.16 \pm 0.145^{\mathrm{a}}$ & $2.80 \pm 0.166^{\mathrm{a}}$ & $2.82 \pm 0.180^{\mathrm{a}}$ & $\begin{array}{l}5.732^{* *} \\
(0.005)\end{array}$ \\
\hline Carbohydrate & $2.54 \pm 0.514^{\mathrm{a}}$ & $0.67 \pm 0.085^{\mathrm{b}}$ & $0.85 \pm 0.151^{\mathrm{b}}$ & $0.30 \pm 0.147^{\mathrm{b}}$ & $\begin{array}{l}12.461^{* *} \\
(<0.001)\end{array}$ \\
\hline Energy & $97.78 \pm 1.45^{\mathrm{b}}$ & $99.51 \pm 1.68^{\mathrm{b}}$ & $102.32 \pm 0.920^{\mathrm{ab}}$ & $106.68 \pm 1.81^{\mathrm{a}}$ & $\begin{array}{l}6.694^{* *} \\
(0.003)\end{array}$ \\
\hline
\end{tabular}

Note**-significant at $1 \%$ level, *-significant at $5 \%$ level, ns-non significant; Means having different alphabets as superscripts are significantly different within a column.

Table 5:-Microbiological parameters of control and treatment cubes.

\begin{tabular}{|l|l|l|}
\hline Sample & Aerobic plate count & Yeast and mould count \\
\hline C & $3.73 \pm 0.630^{\mathrm{c}}$ & $2.84 \pm 0,024^{\mathrm{d}}$ \\
\hline T1 & $4.15 \pm 0.015^{\mathrm{b}}$ & $3.14 \pm 0.036^{\mathrm{b}}$ \\
\hline T2 & $4.40 \pm 0.021^{\mathrm{a}}$ & $3.39 \pm 0.036^{\mathrm{a}}$ \\
\hline T3 & $4.36 \pm 0.017^{\mathrm{a}}$ & $3.04 \pm 0.023^{\mathrm{c}}$ \\
\hline F-value & $77.679^{* * *}$ & $57.313^{* * *}$ \\
\hline
\end{tabular}


\begin{tabular}{|l|l|l}
\hline P-value & $(<0.001)$ & $(<0.001)$
\end{tabular}

Note:**-significant at $1 \%$ level, *- significant at $5 \%$ level, ns-non significant; Means having

different alphabets as superscripts are significantly different within a column.

\section{References:-}

1. Ali, M.S., Kang, G., Yang, H., Jeong, J., Hwang, Y., Park, G. and Joo, S., (2007): A comparison of meat characteristics between duck and chicken breast. Asian-Aust. J. Anim. Sci., 20(6):1002-1006.

2. AOAC. (2012): Meat and meat products. In Official Methods of Analysis of Analytical Chemists. (19 Ed.)Association of Official Analytical Chemists. Inc., Arlington, Virginia. pp. 931-948.

3. Badr, H.M. (2004): Use of irradiation to control food borne pathogens and extend the refrigerated market life of rabbit meat. Meat Sci., 67:541-548.

4. Beuchat, L.R. and Cousin, M.A. (2001): Yeast and Molds. In: Downes, F.P., and Ito, K(ed.), Compendium of Methods for the Microbiological Examination of Foods. (4 ${ }^{\text {th }}$ Ed.). APHA, Washington, D.C. pp. 209-213.

5. Biswas, S., Chakraborty, A. and Sarkar, S. (2006): Comparison among the qualities of patties prepared from chicken broiler, spent hen and duck meats. Int. J. Poult. Sci., 43:180-186.

6. Bourne, M. C. (1978): Texture profile analysis. Food Technol., 32:62-66

7. Chueachuaychoo, A., Wattanachant, S. and Benjakul, S., (2011): Quality characteristics of raw and cooked spent hen Pectoralis major muscles during chilled storage: Effect of salt and phosphate. Int. Food Res. J., 18(2):601-613.

8. Cousin, M.A., Jay, J.M. and Vasavada, P.C. (2001): Psychrotrophic microorganisms. In: Downes, F.P., and Ito, $\mathrm{K}$ (ed.), Compendium of Methods for the Microbiological Examination of Foods. $\left(4^{\text {th }}\right.$ Ed.). APHA, Washington, D.C. pp.159-166.

9. Fletcher, D.L., (2002): Poultry meat quality. World's Poult.Sci. j., 58(2):131-145.

10. Guan, R.F., Ly, F., Chen, X., Ma, J., Jiang, H and Xiao, C. (2013): Meat quality traits offour chines indigenous chicken breeds and one commercial broiler stock. Journal of Zhejiang University-Scince B, 14 (10): 896-902.

11. Gupta, S. and Sharma, B.D., (2016): Storage Quality and Shelf Life of Functional Restructured Spent Hen Meat Blocks in Vacuum Packaging at Refrigerated Storage (4 $\left.\pm 1^{\circ} \mathrm{C}\right)$. Agric. Res, 4(5): 391-397.

12. Kalaikannan, A., Anjaneyulu, A.S.R. and Santhi, D. (2007): Effect of egg proteins on the quality and refrigerated storage life of chicken patties made with broiler-spent hen meat and by-products. Int. J. Food Sci. Technol., 42:579-586

13. Kumar, Y., Singh, P., Tanwar, V.K., Ponnusamy, P., Singh, P.K. and Shukla, P., (2015): Augmentation of quality attributes of chicken tikka prepared from spent hen meat with lemon juice and ginger extract marination. Nutrition \& Food Science, 45(4): 606-615.

14. Lakshani, P., Jayasena, D.D. and Jo, C., (2016): Comparison of Quality Traits of Breast Meat from Commercial Broilers and Spent Hens in Sri Lanka. Korean J. Poult. Sci. 43:55-61.

15. Luckose, F., Pandey, M.C. and Radhakrishna, K., (2015): Development of low salt restructured chicken nugget by response surface methodology and its quality evaluation. Int.Food Res. Journal., 22(6).

16. Morton, R.D. (2001): Aerobic plate count. In: Downes, F.P., and Ito, K (ed.), Compendium of Methods for the Microbiological Examination of Foods. ( $4^{\text {th }}$ Ed.). APHA, Washington, D.C. pp: 63-67.

17. Nowsad, A.A.K.M., Kanoh, S. and Niwa, E., (2000): Thermal gelation characteristics of breast and thigh muscles of spent hen and broiler and their surimi. Meat Sci., 54(2):169-175.

18. Page, J.K., Wulf, D.M. and Schwotzer, T.R. (2001):A survey of beef muscle colour and pH.J. Anim.Sci., 79:678-687.

19. Pearson, D. (1968):Application of chemical method for assessment of beef quality. In Methods related to protein breakdown. J. Sci\&Food Agric. 19:366.

20. Reddy, G.B., Mallika, E.N., Reddy, B.O., Azad, S.A.K. and Reddy, D.M., (2016): comparison on meat quality characteristics of spent breeder, layer and broiler birds. Int. J. Sci. Environ. Technol. 5: 2590 - 2595.

21. Reddy, G.V., Sen, A.R., Reddy, K.S., Reddy, K.K., Rao, T.M. and Kondaiah, N., (2015): Quality characteristics of restructured mutton slices developed by cold-set binding system. Indian Journal of Small Ruminants (The), 21(2):300-305.

22. Singh, V.P., Sanyal, M.K., Dubey, P.C. and Mendirtta, S.K., (2011): Quality assessment of vacuum packaged chicken snacks stored at room temperature. Journal of Stored Products and Postharv Res, 2(6):120-126.

23. Snedecor, G.W. and Cochran, W.G. (1994): Statistical Methods. ( $8^{\text {th }}$ Ed.) The Iowa State University, Ames, Iowa, 313p. 
24. Sudheer, K., Das, C., Mandal, P.K., Pal, U.K. and Rao, V.K., (2011):Effect of frozen storage on the physicochemical, microbiological and sensory quality of low fat restructured chicken block incorporated with gizzard. International Journal of Meat Sci., 1(1):62-69.

25. Swatland, H.J., (2008): How pH causes paleness or darkness in chicken breast meat. Meat Sci. 80:396-400.

26. Talukder, S., Sharma, B.D., Mendiratta, S.K., Kumar, R.R., Malav, O. P. and Rafeh, S., (2014): Development of restructured chicken meat block incorporated with lotus (Nelumbonucifera) root powder. Fleischwirschaft International 5.

27. Witte, V.C., Krause, G.F. and Bailey, M.E. (1970): A new extraction method for determining 2-thiobarbituric acid values of pork and beef during storage. Journal of Food Scince., 35: 582-585. 